УДК 618.14:612.627.015.1

DOI 10.11603/24116-4944.2020.1.11490

๑В. М. Запорожан, Н. М. Рожковська, В. Г. Марічереда, І. С. Ломакіна

Одесъкий національний медичний університет

\title{
РОЛЬ ПОРУШЕНЬ ЛІПІДНОГО ОБМІНУ У ВИНИКНЕННІ АНОМАЛЬНИХ МАТКОВИХ КРОВОТЕЧ У ЖІНОК РЕПРОДУКТИВНОГО ВІКУ
}

\footnotetext{
Мета дослідження - оцінка впливу порушень ліпідного обміну на ризик виникнення аномальних маткових кровотеч у жінок репродуктивного віку.

Матеріали та методи. Обстежено 30 жінок репродуктивного віку з аномальними матковими кровотечами. Проводили аналіз експресії а-рецепторів до естрогенів ER1, рецепторів до прогестерону PgR та ядерного білка Ki-67 у залозах та стромі ендометрія імуногістохімічним методом. Оцінювали показники ліпідограми, визначали індекс маси тіла, проводили антропометрію.
}

Результати дослідження та їх обговорення. При оцінці аліментарного статусу встановлено переважання серед пацієнток осіб з ІМТ>25 кг/м² - 96,7 \%, при цьому ознаки аліментарно-конституційного ожиріння були у 33,3 \%. Середні значення IMT склали $(29,1 \pm 1,6)$ кг/M². Експресія рецепторів до естрогену ER1 була більш високою у залозах (Ме $(25$ \%;75 \%) = 100 (80; 100), аніж у стромі (Ме (25 \%;75 \%) = 80 (60; 90). Натомість, кількість клітин із позитивною реакцією на рецептори до прогестерону PgR у стромі та залозах майже не відрізнялася - Ме (25 \%;75 \%) = 80 (50; 90). Експресія білка Кі-67 була вищою у залозах - (Me $(25 \% ; 75 \%)=90$ (70; 100), у стромі вона не перевищувала $50 \%$ (Mе (25 \%;75 \%) = 40 (30; 50$)$.

Висновки. 1. У пацієнток з аномальними матковими кровотечами часто зустрічаються порушення ліпідного обміну у вигляді дисліпідемії 2b типу. 2. Вираження дисліпідемії корелює з інтенсивністю АМК та експресією маркерів проліферації.

Ключові слова: аномальні маткові кровотечі; гіперплазія ендометрія; рецептори; експресія; ліпідограма; ожиріння.

РОЛЬ НАРУШЕНИЙ ЛИПИДНОГО ОБМЕНА В ВОЗНИКНОВЕНИИ АНОМАЛЬНЫХ МАТОЧНЫХ КРОВОТЕЧЕНИЙ У ЖЕНЩИН РЕПРОДУКТИВНОГО ВОЗРАСТА

Цель исследования - оценка влияния нарушений липидного обмена на риск возникновения аномальных маточных кровотечений у женщин репродуктивного возраста.

Материалы и методы. Обследовано 30 женщин репродуктивного возраста с аномальными маточными кровотечениями. Проводили анализ экспрессии а-рецепторов к эстрогенам ER1, рецепторов к прогестерону PgR и ядерному белку Ki-67 в железах и строме эндометрия иммуногистохимическим методом. Оценивали показатели липидограммы, определяли индекс массы тела, проводили антропометрию.

Результаты исследования и их обсуждение. При оценке алиментарного статуса установлено преобладание среди пациенток лиц с ИМТ>25 кг/м² - 96,7 \%, при этом признаки алиментарно-конституционального ожирения были у 33,3 \%.

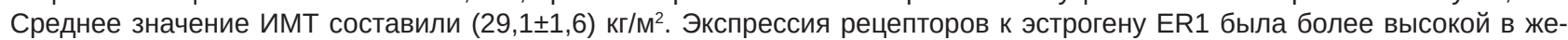
лезах (Ме $(25 \% ; 75$ \%) = 100 (80; 100), чем в строме (Ме (25 \%; 75 \%) = 80 (60; 90). Количество клеток с положительной реакцией на рецепторы к прогестерону PgR в строме и железах практически не отличалось Ме (25 \%; 75 \%) = 80 (50, 90$)$. Экспрессия белка Кі-67 была выше в железах - (Ме (25 \%; 75 \%) = 90 (70; 100), в строме она не превышала 50 \% (Ме (25 \%; $75 \%)=40(30 ; 50)$.

Выводы. 1. У пациенток с аномальными маточными кровотечениями часто встречаются нарушения липидного обмена в виде дислипидемии 2b типа. 2. Выраженность дислипидемии коррелирует с интенсивностью АМК и экспрессией маркеров пролиферации.

ключевые слова: аномальные маточные кровотечения; гиперплазия эндометрия; рецепторы; экспрессия; липидограмма; ожирение. WOMEN

THE ROLE OF LIPID METABOLISM DISORDERS IN THE ABNORMAL UTERINE BLEEDING IN REPRODUCTIVE AGE

The aim of the study - to assess the effect of lipid metabolism disorders on the risk of abnormal uterine bleeding in women of reproductive age.

Materials and Methods. Thirty women of reproductive age with abnormal uterine bleeding were examined. The expression of $\alpha$-receptors for estrogen ER1, receptors for progesterone PgR and nuclear protein Ki-67 in the glands and stroma of the endometrium was performed by immunohistochemical method. Lipidogram parameters were evaluated, body mass index was determined, and anthropometry was performed.

Results and Discussion. When assessing nutritional status, the prevalence among patients of $\mathrm{BMI}>25 \mathrm{~kg} / \mathrm{m}^{2}$ was found to be $96.7 \%$, while signs of nutritional constitutional obesity were $33.3 \%$. The average BMI was (29.1 1.6$) \mathrm{kg} / \mathrm{m}^{2}$. The expression of estrogen receptors ER1 was higher in the glands (Me $(25 \% ; 75 \%)=100(80 ; 100)$ than in the stroma $(\mathrm{Me}(25 \% ; 75 \%)=80(60 ;$ 90). On the other hand, the number of cells with a positive reaction to PgR progesterone receptors in the stroma and glands did not practically differ in Me $(25 \% ; 75 \%)=80(50,90)$. The expression of Ki-67 protein was higher in glands $-(\mathrm{ME}(25 \% ; 75 \%)=$ $90(70 ; 100)$, in the stroma it did not exceed $50 \%((\mathrm{Me}(25 \% ; 75 \%)=40(30 ; 50)$.

Conclusions. 1. In patients with abnormal uterine bleeding, lipid disturbances in the form of type $2 \mathrm{~b}$ dyslipidemia are often found. 2. The severity of dyslipidemia correlates with the intensity of abnormal uterine bleedings and the expression of proliferation markers.

Key words: abnormal uterine bleeding; endometrial hyperplasia; receptors; expression; lipid profile; obesity. 
ВСТУП. Аномальні маткові кровотечі (АМК) є найпоширенішою причиною звернення до гінеколога, яка вимагає інвазивних діагностичних тестів, таких як біопсія ендометрія або гістероскопія [1]. За даними епідеміологічних досліджень, у 3 \% випадків причинами АМК є атипова гіперплазія або рак ендометрія (PE). Атипова гіперплазія ендометрія (ГПЕ) розглядається як передрак, причому в етіології цього стану основне місце займає стійка тривала стимуляція ендометрія естрогенами, зокрема при наявності частих ановуляторних циклів [2]. Фізіологічна ановуляція відбувається під час періоду пременопаузи, але у жінок із синдромом полікістозних яєчників або ожирінням нерідко відзначаються ановуляторні цикли.

Важливим прогностичним маркером при гіперпластичних процесах ендометрія $€$ наявність ядерної атипії. у 28-40\% жінок із атиповою гіперплазією ендометрія можлива малігнізація, у деяких випадках на момент біопсії визначається не лише атипова гіперплазія, але й нерозпізнана співіснуюча аденокарцинома [3, 4]. Загальновизнаними фракторами ризику розвитку PE $€$ вік, ожиріння, часті аборти, безпліддя і пізня менопауза. Певну роль відіграє обтяжений спадковий анамнез, сімейні випадки РЕ складають до 10 \% випадків, у 2-5 \% - при так званому синдромі Лінча (спадковий неполіпозний колоректальний рак) [4]. Високий ступень асоціації з $\mathrm{PE}$ мають також цукровий діабет [6], артеріальна гіпертензія та куріння, натомість використання комбінованих оральних контрацептивів може мати превентивний ефект [7].

За останні два десятиліття у світі значно зросла кількість людей, що страждають від ожиріння. Декілька систематичних оглядів показали зв'язок між ожирінням та PE [8]. Однак, враховуючи, що більшість випадків РЕ зустрічається в жінок після менопаузи [9], даних щодо впливу порушень ліпідного обміну та ожиріння на ризик розвитку ГПЕ та РЕ у жінок репродуктивного віку небагато [10]. Водночас, більш глибоке розуміння провідних факторів ризику для жінок в пременопаузі може дозволити не лише оптимізувати діагностику та лікування, але й значно покращити фрункціональні резерви організму хворих.

МЕТА ДОСЛІДЖЕННЯ - оцінка впливу порушень ліпідного обміну на ризик виникнення аномальних маткових кровотеч у жінок репродуктивного віку.

МАТЕРІАЛИ ТА МЕТОДИ. Дослідження проведено на базі Університетської клініки ОНМедУ (Багатопрофрільний медичний центр, Центр реконструктивної та відновної медицини). Всього обстежено 30 жінок репродуктивного віку 3 аномальними матковими кровотечами, які склали основну групу. Для контролю обстежено 30 практично здорових жінок того ж віку, що проходили обстеження з приводу чоловічого фактора неплідності. При оцінці клінічних маніфестацій та етіології АMK використовували класифрікацію FIGO PALMCOEIN [11]. Інтенсивність АМК оцінювали за Янсеном.

Проведено аналіз експресії $\alpha$-рецепторів до естрогенів ER1, рецепторів до прогестерону PgR та ядерного білка Кi-67 у стромі та залозах ендометрія імуногістохімічним методом (Dako, клони EP1, PgR 636, MIB-1, Велика Британія). Зразки тканин одержували під час гістероскопічних втручань. Додатково проводили гістологічне дослідження 3 мікроморорометрією та розрахунком критерію D-score $=0.6229+0.0439 \times$ (об'ємний \% строми $)-3.9934 \times$ Ln (SD найкоротшого діаметра ядра) - $0.1592 \times$ (щільність клітин залозистого епітелію).
Стан ліпідного обміну визначали за показниками ліпідограми (загальний холестерин, ЛПВщ, лПНЩ, лПдНЩ, тригліцериди, бета-ліпопротеїди) [12]. У всіх хворих визначали індекс маси тіла, проводили антропометрію, каліперометрію із розрахунком «жирової» маси тіла за формулами Pallafolls [13].

Статистичну обробку виконували за допомогою програмного забезпечення Statistica 13.0 (StatSoft Dell, США).

РЕЗУЛЬТАТИ ДОСЛІДЖЕННЯ ТА ЇХ ОБГОВОРЕННЯ. Середній вік обстежених жінок склав $(44,1 \pm 1,3)$ року. Основними причинами АМК були ГПЕ (63,3 \%), аденоміоз $(36,7 \%)$, поліпи ендометрія (10,0 \%), міома матки (23,3\%). У більшості обстежених пацієнток (93,3 \%) переважали випадки коморбідного ураження.

За інтенсивністю АМК відповідали помірній крововтра-

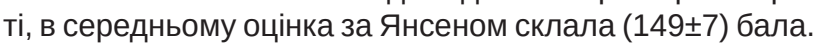

До оперативного втручання значення D-score в ceредньому складало $(1,77 \pm 0,11)$, що свідчить про малий ризик малігнізації. Мікроскопічно визначалася надмірна кількість залоз із їх нерівномірним розподілом, деякі залози були кістозно розширені, визначалися стратифріковані гіперхромні ядра. Експресія рецепторів до естрогену ER1 була більш високою у залозах (Me $(25 \% ; 75 \%)=$ $100(80 ; 100)$, ніж у стромі $(\mathrm{Me}(25 \% ; 75 \%)=$ 80 (60; 90). Натомість, кількість клітин з позитивною реакцією на рецептори до прогестерону PgR у стромі та залозах майже не відрізнялася - Me $(25 \% ; 75 \%)=80$ (50; 90). Експресія білка Кі-67 була вищою у залозах - (Ме (25\%;75\%) = $90(70 ; 100)$, у стромі вона не перевищувала $50 \%$ $(\mathrm{Me}(25 \% ; 75 \%)=40(30 ; 50)$.

При оцінці аліментарного статусу встановлено переважання серед пацієнток осіб з ІМT>25 кг/M² - 96,7\%, при цьому ознаки аліментарно-конституційного ожиріння були у 33,3 \%. Середні значення IMT склали $(29,1 \pm 1,6) \mathrm{kr} / \mathrm{M}^{2}$.

За результатами каліперометрії пацієнтки розподілилися таким чином (рис. 1).

Наведені значення свідчать про надмірний розвиток підшкірно-жирової клітковини. Подальший розрахунок жирової маси показав, що вона не перевищує $25 \%$, складаючи в середньому $(19,6 \pm 1,2) \%$.

Аналіз ліпідограми (табл. 1) показав наявність дисліпідемії Ilb типу (комбінованої гіперліпідемії) у всіх обстежених пацієнток, при цьому вираження дисліпідемії тісно корелювало з інтенсивністю АМК $(r=0,64)$.

Як відомо, основними етіологічними чинниками виникнення комбінованої гіперліпідемії є зниження експресії лПнЩ-рецепторів та підвищення продукції аполіпопротеїну В (апоВ). Останній є єдиним аполіпопротеїном лПнЩ, носієм «поганого холестерину», що викликає накопичення холестерину в стінках кровоносних судин. АпоВ $€$ також основним аполіпопротеїном хіломікронів, ліпопротеїнів дуже низької щільності та їх залишків. АпоВ є лігандом для лПНЩ-рецептора, що важливо для деградації ліпопротеїнів низької щільності в печінці. Водночас апоВ бере участь у цитокіновому каскаді, який деякими авторами розглядається як основний чинник активації проліферативних процесів в ендометрії [14].

При зіставленні вираження дисліпідемії та екпресії окремих маркерів гормонального дисбалансу та проліферації встановлено наявність кореляційних зв'язків середньої сили між значеннями коефіцієнта атерогенності та експресією білка Кі-67 (табл. 2). 


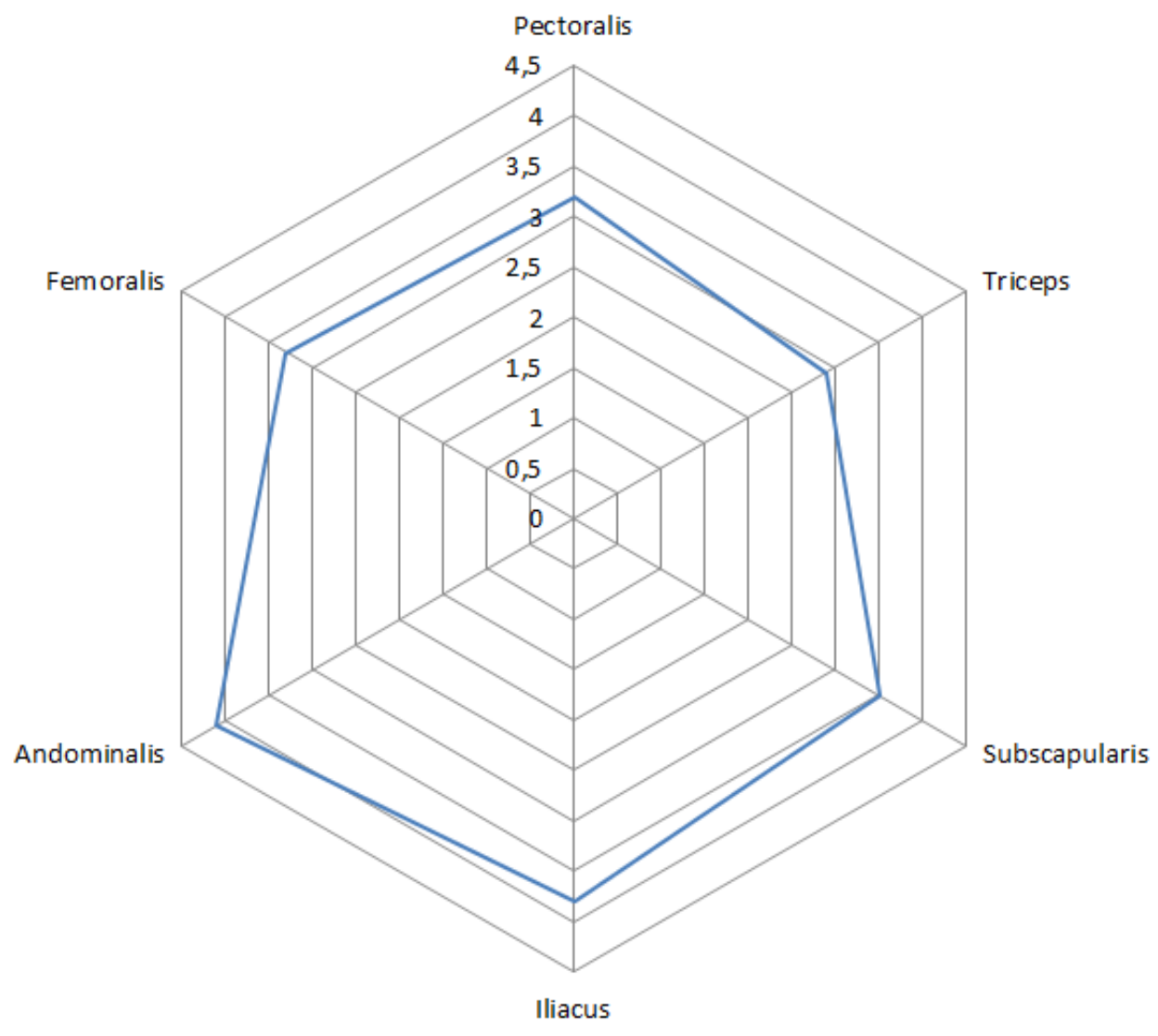

Рис. 1. Результати каліперометрії у хворих з АМК.

Таблиця 1. Ліпідний профіль пацієнток

\begin{tabular}{|c|c|c|}
\hline Показники & 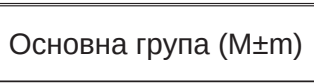 & $\begin{array}{c}\text { Контрольна група } \\
(\mathrm{M} \pm \mathrm{m})\end{array}$ \\
\hline Холестерин, загальний, ммоль/л & $6,1 \pm 0,4$ & $5,2 \pm 0,2$ \\
\hline ЛПВП, ммоль/л & $0,9 \pm 0,1^{*}$ & $1,6 \pm 0,1$ \\
\hline Тригліцериди, ммоль/л & $4,4 \pm 0 *$ & $1,6 \pm 0,3$ \\
\hline ЛПНП, ммоль/л & $3,1 \pm 0,2^{*}$ & $1,9 \pm 0,3$ \\
\hline ß-ліпопротеїди, од & $90 \pm 8^{*}$ & $45 \pm 5$ \\
\hline Коефріцієнт атерогенності & $5,8 \pm 0,5^{\star}$ & $3,2 \pm 0,4$ \\
\hline
\end{tabular}

Примітка. * $-p<0,05$.

Таблиця 2. Вплив дисліпідемії на експресію біомаркерів ендометрія

\begin{tabular}{|c|c|c|c|}
\hline & ER1 & PgR & Ki-67 \\
\hline KA & 0,52 & 0,38 & 0,59 \\
\hline
\end{tabular}

Виявлені закономірності можуть свідчити про залученість порушень ліпідного обміну у проліферації не лише на рівні збільшення ймовірної конверсії андрогенів в естрогени, але й шляхом активації пере- кисного окиснення ліпідів, з фрормуванням окисного стресу [15-24].

ВИСНОВКИ. 1. У пацієнток з аномальними матковими кровотечами часто зустрічаються порушення ліпідного обміну у вигляді дисліпідемії 2b типу.

2. Вираження дисліпідемії корелює з інтенсивністю АМК та експресією маркерів проліфрерації.

ПЕРСПЕКТИВИ ПОДАЛЬШИХ ДОСЛІДЖЕНЬ пов'язані із опрацюванням проблеми впливу дисліпідемії на інтенсивність перекисного окиснення ліпідів у пацієнток із патологією ендометрія. 


\section{СПИСОК ЛІТЕРАТУРИ}

1. Goldstein S. R. Abnormal uterine bleeding in perimenopause/ S. R. Goldstein, M. A. Lumsden // Climacteric. - 2017. Vol. 20 (5). - P. 414-420.

2. Al Nemer A. M. The accuracy of endometrial sampling for the diagnosis of patterns of endometrial pathology in women presenting with abnormal uterine bleeding / A. M. Al Nemer, M. I. Al Bayat, N. H. Al Qahtani // More conservative therapeutic approaches. - Saudi. Med. J. - 2019. - Vol. 40 (8). - P. 815-819.

3. llavarasi C. R. Study of the efficacy of pipelle biopsy technique to diagnose endometrial diseases in abnormal uterine bleeding / C. R. Ilavarasi, G. S. Jyothi, N. K. Alva // J. Midlife. Health. - 2019. - Vol. 10 (2). - P. 75-80.

4. Вивчення впливу віку та індексу коморбідності на ризик тромботичних ускладнень у хворих на рак ендометрія на доопераційному етапі / Б. Д. Кривокульський, І.В.Жулкевич, Д. Б. Кривокульський, Л.В.Шкробот // Вісник наукових досліджень. - 2018. - № 2 (91). - С. 151-153. https:// doi.org/10.11603/2415-8798.2018.2.9212

5. Prediction of endometrial hyperplasia and cancer among premenopausal women with abnormal uterine bleeding / L. Giannella, L. B. Cerami, T. Setti, E. Bergamini, F. Boselli // BioMed. Res. Int. - 2019. - 2019. - 8598152.

6. Indicators of lipid metabolism and their relation to disorders of microcirculation in diabetes mellitus / F. A. ZvershanovskiǏ, I. V. Zhulkevich, V. S. Danilishina, G. D. Zhulkevich // Problemy Endokrinologii. - 1987. Vol. 33 (4). - P. 15-18.

7. Wouk N. Abnormal uterine bleeding in premenopausal women / N. Wouk, M.b Helton // Am. Fam. Physician. - 2019. - Vol. 99 (7). - P. 435-443.

8. Vannuccini S. Recent advances in understanding and managing adenomyosis / S. Vannuccini, F. Petraglia // F1000Res. - 2019. - Vol. 8. pii: F1000 Faculty Rev-283.

9. Жулкевич І. В. Персоналізація в онкології: індивідуальний підхід до профрілактики тромбоемболіч них ускладнень при пангістеректомії / І. В. Жулкевич, Б. Д. Кривокульський // Вісник соціальної гігієни та організації охорони здоров'я України. - 2018. - № 4. - С. 11-18.

10. Establishing patterns on hysteroscopy in abnormal uterine bleeding (AUB) / D. Pandey, S. Kunamneni, P. R. Inukollu, H. Su // Gynecol. Minim. Invasive Ther. - 2017. - Vol. 6 (4). - P. 178-182.

11. Munro M. G. FIGO Menstrual Disorders Committee. The two FIGO systems for normal and abnormal uterine bleeding symptoms and classification of causes of abnorma uterine bleeding in the reproductive years: 2018 revisions / M. G. Munro, H. O. D. Critchley, I. S. Fraser // Int. J. Gynaecol. Obstet. - 2018. - Vol. 143 (3). - P. 393-408.

\section{REFERENCES}

1. Goldstein, S.R., \& Lumsden, M.A. (2017). Abnormal uterine bleeding in perimenopause. Climacteric., 20 (5), 414-420.

2. Al Nemer, A.M., Al Bayat, M.I., \& Al Qahtani, N.H. (2019). The accuracy of endometrial sampling for the diagnosis of patterns of endometrial pathology in women presenting with abnormal uterine bleeding. More conservative therapeutic approaches. Saudi. Med. J., 40 (8), 815-819.

3. Ilavarasi, C.R., Jyothi, G.S., \& Alva, N.K. (2019). Study of the efficacy of pipelle biopsy technique to diagnose endometrial diseases in abnormal uterine bleeding. J. Midlife Health, 10 (2), 75-80.
12. Zhulkevich I. V. Algorithm for phenotyping hyperlipoproteinemias and its application to the" Elektronika BZ-21" microcalculator / I. V. Zhulkevich, S. G. Vaĭnshtein // Laboratornoe delo. - 1986. - No. 10. - P. 623-625.

13. Relation of metabolic syndrome with endometrial pathologies in patients with abnormal uterine bleeding / S. Özdemir, G. Batmaz, S. Ates [et al.] // Gynecol. Endocrinol. - 2015. - Vol. 31 (9). - P. 725-729.

14. A prospective clinical cohort study of women at increased risk for endometrial cancer / M. A. Clarke, B. J. Long, M. E. Sherman [et al.] // Gynecol. Oncol. - 2020. Vol. 156 (1). - P. 169-177.

15. Antioxidant status in blood of gynaecological patients: influence of diagnosis and reproductive factors / S. Pejić, V. Stojiljković, A. Todorović [et al.] // Folia Biol. - 2015. Vol. 61 (1). - P. 26-32.

16. Antioxidant enzymes and lipid peroxidation in endometrium of patients with polyps, myoma, hyperplasia and adenocarcinoma / S. Pejić, A. Todorović, V. Stojiljković [et al.] // Reprod. Biol. Endocrinol. - 2009. - Vol. 7. - P. 149.

17. Clinical and metabolic response to vitamin D supplementation in endometrial hyperplasia: a randomized, double-blind, placebocontrolled trial / Z. Tabassi, S. Bagheri, M. Samimi [et al.] // Horm. Cancer. - 2017. - Vol. 8 (3). - P. 185-195.

18. Peng F. Postmenopausal estrogen, lipid metabolism and atherosclerosis / F. Peng, W. Ding // Zhonghua Xin Xue Guan Bing Za Zhi. - 2015. - Vol. 43 (2). - P. 130-133.

19. Sitruk-Ware R. Metabolic effects of contraceptive steroids / R. Sitruk-Ware, A. Nath // Rev. Endocr. Metab. Disord. - 2011. - Vol. 12 (2). - P. 63-75.

20. Grant E. C. Oral contraceptive progestin and estrogen use and increases in breast, ovarian, and endometrial cancers / E. C. Grant // JAMA Oncol. - 2018. - Vol. 4 (11). - P. 1623.

21. Broughton D. E. Obesity and female infertility: potential mediators of obesitys impact / D. E. Broughton, K. H. Moley // Fertil. Steril. - 2017. - Vol. 107 (4). - P. 840-847.

22. Lipid profiling of peri-implantation endometrium in patients with premature progesterone rise in the late follicular phase / J. Li, Y. Gao, L. Guan [et al.] // J. Clin. Endocrinol. Metab. - 2019. - Vol. 104 (11). - P. 5555-5565.

23. Elevated non-esterified fatty acids impair survival and promote lipid accumulation and pro-inflammatory cytokine production in bovine endometrial epithelial cells / W. Chankeaw, Y. Z. Guo, R. Båge [et al.] // Reprod. Fertil. Dev. - 2018. Vol. 30 (12). - P. 1770-1784.

24. Clues to Non-Invasive Implantation Window Monitoring: Isolation and Characterisation of Endometrial Exosomes / A. Luddi, N. Zarovni, E. Maltinti [et al.] // Cells. - 2019. Vol. 8 (8). - P. 811.

4. Kryvokulsky, B.D., Zhulkevich, I.V., Kryvokulsky, D.B., \& Shkrobot, L.V. (2018). Vyvchennia vplyvu viku ta indeksu komorbidnosti na ryzyk trombotychnykh uskladnen u khvorykh na rak endometriia na dooperatsiinomu etapi [Studying the influence of age and comorbidity index on the thrombotic complications risk in patients with endometrial cancer at preoperative stage]. Visnyk naukovykh doslidzhen - Bulletin of Scientific Research, 2 (91), 151-153. Retrieved from: https://doi. org/10.11603/2415-8798.2018.2.9212 [in Ukrainian].

5. Giannella, L., Cerami, L.B., Setti, T., Bergamini, E., \& Boselli, F. (2019). Prediction of endometrial hyperplasia and 
cancer among premenopausal women with abnormal uterine bleeding. BioMed. Res. Int., 2019, 8598152.

6. Zvershanovskiĭ, F.A., Zhulkevich, I.V., Danilishina, V.S., \& Zhulkevich, G.D. (1987). Indicators of lipid metabolism and their relation to disorders of microcirculation in diabetes mellitus. Problemy Endokrinologii, 33 (4), 15-18.

7. Wouk, N., \& Helton, M. (2019). Abnormal uterine bleeding in premenopausal women. Am. Fam. Physician., 99 (7), 435-443.

8. Vannuccini, S., \& Petraglia, F. (2019). Recent advances in understanding and managing adenomyosis. F1000Res., 8.

9. Zhulkevych, I.V., \& Kryvokulskyi, B.D. (2018). Personalizatsiia $v$ onkolohii: indyvidualnyi pidkhid do profilaktyky tromboembolichnykh uskladnen pry panhisterektomii [Personalization in oncology: individual approach to the prevention of thromboembolic complications during hysterectomy]. Visnyk sotsialnoi hihiieny ta orhanizatsii okhorony zdorovia Ukrainy - Bulletin of Social Hygiene and Health Protection Organization of Ukraine, 4, 11-18 [in Ukrainian].

10. Pandey, D., Kunamneni, S., Inukollu, P.R., \& Su, H. (2017). Establishing patterns on hysteroscopy in abnormal uterine bleeding (AUB). Gynecol. Minim. Invasive Ther., 6 (4), 178-182.

11. Munro, M.G., Critchley, H.O.D., \& Fraser, I.S. (2018). FIGO Menstrual Disorders Committee. The two FIGO systems for normal and abnormal uterine bleeding symptoms and classification of causes of abnormal uterine bleeding in the reproductive years: 2018 revisions. Int. J. Gynaecol. Obstet., 143 (3), 393-408.

12. Zhulkevich, I.V., \& Vainshtein, S.G. (1986). Algorithm for phenotyping hyperlipoproteinemias and its application to the" Elektronika BZ-21" microcalculator. Laboratornoe delo, 10, 623-625.

13. Özdemir, S., Batmaz, G., Ates, S., Celik, C., Incesu, F., \& Peru, C. (2015). Relation of metabolic syndrome with endometrial pathologies in patients with abnormal uterine bleeding. Gynecol. Endocrinol., 31 (9), 725-729.

14. Clarke, M.A., Long, B.J., Sherman, M.E., Lemens, M.A., Podratz, K.C., Hopkins, M.R., ..., \& Bakkum-Gamez, J.N. (2020). A prospective clinical cohort study of women at increased risk for endometrial cancer. Gynecol. Oncol., 156 (1), 169-177.
15. Pejić, S., Stojiljković, V., Todorović, A., Gavrilović, L., Popović, N., Pavlović, I., \& Pajović, S.B. (2015). Antioxidant status in blood of gynaecological patients: influence of diagnosis and reproductive factors. Folia Biol. (Praha), 61 (1), 6-32.

16. Pejić, S., Todorović, A., Stojiljković, V., Kasapović, J., \& Pajović, S.B. (2009). Antioxidant enzymes and lipid peroxidation in endometrium of patients with polyps, myoma, hyperplasia and adenocarcinoma. Reprod. Biol. Endocrinol., 7, 149.

17. Tabassi, Z., Bagheri, S., Samimi, M., Gilasi, H.R., Bahmani, F., Chamani, M., \& Asemi, Z. (2017). Clinical and metabolic response to vitamin $D$ supplementation in endometrial hyperplasia: a randomized, double-blind, placebo-controlled trial. Horm. Cancer, 8 (3), 185-195.

18. Peng, F., \& Ding, W. (2015). Postmenopausal estrogen, lipid metabolism and atherosclerosis. Zhonghua Xin Xue Guan Bing Za Zhi, 43 (2), 130-133.

19. Sitruk-Ware, R., \& Nath, A. (2011). Metabolic effects of contraceptive steroids. Rev. Endocr. Metab. Disord., 12 (2), 63-75.

20. Grant, E.C. (2018). Oral contraceptive progestin and estrogen use and increase in breast, ovarian, and endometrial cancers. JAMA Oncol., 4 (11), 1623.

21. Broughton, D.E., \& Moley, K.H. (2017). Obesity and female infertility: potential mediators of obesity's impact. Fertil. Steril., 107 (4), 840-847.

22. Li, J., Gao, Y., Guan, L., Zhang, H., Chen, P., Gong, X., ..., \& $\mathrm{Bi}, \mathrm{H}$. (2020). Lipid profiling of peri-implantation endometrium in patients with premature progesterone rise in the late follicular phase. J. Clin. Endocrinol. Metab., 104 (11), 5555-5565.

23. Chankeaw, W., Guo, Y.Z., Båge, R., Svensson, A., Andersson, G., \& Humblot, P. (2018). Elevated non-esterified fatty acids impair survival and promote lipid accumulation and pro-inflammatory cytokine production in bovine endometrial epithelial cells. Reprod. Fertil. Dev., 30 (12), 1770-1784.

24. Luddi, A., Zarovni, N., Maltinti, E., Governini, L., De Leo, V., Cappelli, V., Piomboni, P. (2019). Clues to non-invasive implantation window monitoring: isolation and characterisation of endometrial exosomes. Cells, 8 (8), 811.

Отримано 22.05.20 Прийнято до друку 19.06.20

Електронна адреса для листування: rysana23@gmail.com 